\title{
Peculiarities of the First Year University Students' Motivation for Learning in Samples of Riga and Smolensk
}

\author{
Delena Jermolajeva ${ }^{1}$ Dr. paed.; (Dvetlana Silchenkova ${ }^{2} \mathrm{PhD}$; (D) Larissa Turusheva ${ }^{3}$ Dr. paed. \\ EKA University of Applied Sciences, Latvia ${ }^{1,3}$ \\ Smolensk State University, Russia ${ }^{2}$ \\ jjerm@latnet.lv1, sil-sv@mail.ru², larisa.turuseva@eka.edu.lv³
}

\begin{abstract}
The demand for tertiary education among young people is growing worldwide. However, in the first months of the studies, freshmen face increasing difficulties, which sometimes negatively affect their learning motivation. For the successful pedagogical process, teachers need to study the motivation of students of the first study year, monitor it and take into account its peculiarities while developing learning materials and choosing educational strategies. The article presents the results of an international study of freshmen's motivation. The study aim to compare the motivation of the first-year students at the universities of Riga and Smolensk, to identify prevailing motives and to assess the impact of the psychological atmosphere in the student group on their motivation. In the survey carried out in December 2019, 129 students from two universities in Riga (Latvia) and Smolensk (Russia) participated. The tools for collecting information were the technique of diagnostics of learning motivation by 7 content scales and the technique of measuring the psychological climate in the collective by 10 bipolar scales. For data processing, descriptive statistics, analysis of statistical indicators, and Spearman correlation analysis were used. In both national samples, professional motives for learning prevail over other motives, while prestige motives and avoidance motives take the penultimate and last place relatively. The importance of other groups of learning motives is assessed somewhat differently. For the Smolensk sample of students it was found out that their motivation to learn depends on the psychological atmosphere in the group, especially on the overall atmosphere of success in the group. However a similar correlation has not been revealed in the survey of the Riga sample of students. The study shows that a few months after the start of studying, the first-year students' overall motivation has not dropped below the critical level. However, for more successful training, it could and should be improved. Some ways to increase freshmen's motivation for learning are proposed in the article.
\end{abstract}

Keywords: first year university students, learning motivation, psychological atmosphere in the student group.

\section{Introduction}

Despite mounting criticism of formal tertiary education (Kromydas, 2017; Bartram, 2020), the demand for it among young people is growing. According to the estimation by Organisation for Economic Co-operation and Development (OECD), if current entry patterns persist, $49 \%$ of young adults across OECD countries will enter tertiary education in 2021; the prognostic rate of those who will graduate this year is $38 \%$ (OECD, 2020). The mass desire of young people for higher education, however, is at odds with another modern sociocultural trend, which is a certain infantilisation of some part of the youth, expressed in the reluctance of adolescents and young people to make great efforts in their studies, the inability to take responsibility for their own future, the preference for entertainment to other kinds of pastimes (Gottschalk, 2018; Hartwell-Walker, 2018; Baljukova, Jakovleva, 2020). University educational programs (levels 5 and 6 according to the International Standard Classification of Education (ISCED)) are more complex than educational programs of the 4th and below levels, and require a long time to acquire them. For example, ISCED level 5 has a minimum duration of 2 years. Unsurprisingly, that for many students studying at the university becomes a hard test; it is sometimes the first serious test in their lives.

To successfully overcome difficulties, motivation is necessary, which corresponds with the difficulty level of a task (Maslow, 1954; Illeris, 2009; Safronova, Klyukina, 2019). However, research shows that the learning motivation of freshmen in the first months of studying somehow declines. The reasons may be the gap between the school and university systems of education, lack of skills of independent work, inability to plan their time to orienteering in a large flow of information, lack of understanding of the specifics of university education, which involves the study of a number of fundamental disciplines not 
related directly to the chosen specialty (Birzina, Cedere, 2017; Borzilova, 2015; Howey, 2008). Former secondary school students are experiencing an inner conflict: their notions of studying at the university and the future profession come into conflict with the realities of academic requirements and with difficulties that sometimes seem insurmountable, which leads to high dropouts (Bustamante, 2020). Helping students to get used to the new educational environment, to turn the conflict of expectations with objective reality into a point of growth in academic, professional and personal terms is an important task of the university academic staff (Boekaerts, 2010; Rizkallah, Seitz, 2017). A constructivist approach to education as a paradigm shift from teaching to learning with an emphasis on active individual's intelligence organization and immediate construction of new information from experience is a quite serious challenge in contemporary higher education. Constructivism principles help to understand and evaluate competence development of a teacher in the role of a facilitator in a positive and supportive learning environment (Briede, Peks, 2014). Sustained academic motivation of freshmen is an important factor and resource for successful studying at the university and, as a result, graduating. Therefore, teachers need to study the learning motivation of students in the first study year, closely monitor it, and take into account its peculiarities in the development of study materials and the choice of educational strategies.

This article is the second stage of an international research project dedicated to the academic motivation of students. The project was started by the authors of the article in 2018 and has been carried out on the basis of Smolensk State University (Russia) and EKA University of Applied Sciences (Riga, Latvia; the official English name of the university includes the abbreviation of its Latvian name: Ekonomikas un Kultüras Augstskola). The first phase of the project was analysing the data of a survey of graduates who retrospectively assessed their academic motivation during their studies at the university (Jermolajeva, Silchenkova, Turusheva, 2020a, 2020b). The second stage of the project is devoted to the learning motivation of freshmen.

The aim of the study is to compare the motivation of the first-year students at the universities of Riga and Smolensk, to identify the prevailing motives and to assess the impact of the psychological atmosphere in the student group on their motivation.

\section{Methodology}

Two techniques have been used to collect the data; the main is the "Diagnostics of learning motivation of students" by N. Badmayeva. It provides an opportunity to determine the level of motivation on seven content scales, which structure, in a compact and at the same time exhaustive way, many diverse motives that affect the attitude of students to studying (Badmayeva, 2004).

- Scale 1: communication motives that show how much the student is motivated to communicate with their fellow students and, in the future, with colleagues.

- Scale 2: motives of avoidance, demonstrating how the respondent is forced to learn in order not to lag behind their fellow students and avoid condemnation.

- Scale 3: motives of prestige, showing the desire to be the best in everything.

- Scale 4: professional motives that demonstrate a focus on acquiring a profession.

- Scale 5: motives of creative self-realisation, which show how much the interviewee wants to be realised as a creative personality.

- Scale 6: educational and cognitive motives that show the desire to gain knowledge.

- Scale 7: social motives that demonstrate the desire to be successful in the society.

For each scale, the student was offered several statements (from 2 to 7 ), each of which can be evaluated by a 5-point system: 1 point means the minimum value of the motive, 5 points mean the maximum. There are 34 statements in the questionnaire in total. The following scale is used to determine motivation levels in the group: the average value from 1 to 2.3 points is a low level of motivation, 2.4 to 3.6 points is the average one, 3.7 to 5 points is a high level of motivation.

The study also used the A.F. Fidler's technique of assessing the psychological atmosphere in the team, based on the Semantic Differential Technique (Fetiskin, Kozlov, Manujlov, 2002, 134). The survey template contains 10 opposite pairs of words, which form a set of 10 bipolar scales in the space of relationships within the team:

- friendliness - hostility; 
- consent - dissent;

- $\quad$ satisfaction - dissatisfaction;

- fascination - indifference;

- productivity - unproductivity;

- warmth - coldness;

- cooperation - lack of cooperation;

- mutual support - unkindness;

- attraction - boredom;

- $\quad$ success - failure.

The student was asked to rate each bipolar scale from one point (extreme expression of the positive trait in a pair) to 8 (extreme severity of the negative trait). The lower the scores, the better the atmosphere in the group.

The survey involved 129 freshmen from two universities: Latvia's EKA University of Applied Sciences (EKA) - 67 students, and Russia's Smolensk State University (SmolSU) - 62 students. Students of Smolensk University are studying in economic area of training, Riga EKA - in the areas of economics, information technology and design. The survey among freshmen was conducted a few months after the beginning of the study year (December 2019), when some above-mentioned decrease in the initial motivation had already occurred. The time of the survey was also chosen with the expectation that students would be able to appreciate the atmosphere of the recently formed student group.

Data analysis methods are table method, descriptive statistics, statistical analysis, comparison method, Spearman correlation analysis.

\section{Results and Discussion}

Analysing the data on educational motivation of students, the Cronbach's alfa coefficient for each of the two samples was calculated. In the Riga sample, it is 0.974, for Smolensk freshmen -0.968 . The high value of the indicator shows a high internal consistency of the data. For both national samples, the following descriptive statistics were calculated for 34 statements and 7 scales: mean value, mode (the most common assessment), dispersion, and coefficient of variation, showing the fluctuation of answers.

Table 1 presents the main statistical indicators by the groups of motives for EKA and SmolSU students, and in general for the questionnaire.

Table 1

Statistical indicators of the learning motivation of the first-year students of Riga and Smolensk by groups of motives and in general on the questionnaire

\begin{tabular}{|l|c|c|c|c|c|c|c|c|}
\hline \multirow{2}{*}{$\begin{array}{c}\text { Scale of learning } \\
\text { motivation }\end{array}$} & $\begin{array}{c}\text { Mean } \\
(M)\end{array}$ & $\begin{array}{c}\text { Mode } \\
(M d n)\end{array}$ & $\begin{array}{c}\text { Disper- } \\
\text { sion }\end{array}$ & $\begin{array}{c}\text { Coefficient } \\
\text { of variation } \\
(C o V, \%)\end{array}$ & $\begin{array}{c}\text { Mean } \\
(M)\end{array}$ & $\begin{array}{c}\text { Mode } \\
(M d n)\end{array}$ & $\begin{array}{c}\text { Disper- } \\
\text { sion }\end{array}$ & $\begin{array}{c}\text { Coefficient } \\
\text { of variation } \\
(C o V, \%)\end{array}$ \\
\hline $\begin{array}{l}\text { Communication } \\
\text { motives }\end{array}$ & 3.46 & 3 & 1.51 & 35.52 & 3.51 & 4 & 1.35 & 33.10 \\
\hline Avoidance motives & 2.40 & 1 & 1.64 & 53.36 & 2.47 & 1 & 1.57 & 50.73 \\
\hline Prestige motives & 2.93 & 1 & 2.02 & 48.51 & 3.1 & 4 & 1.56 & 40.29 \\
\hline $\begin{array}{l}\text { Professional } \\
\text { motives }\end{array}$ & $\mathbf{4 . 3 0}$ & 5 & 0.76 & 20.27 & $\mathbf{3 . 7 0}$ & 4 & 1.48 & 32.88 \\
\hline $\begin{array}{l}\text { Creative self- } \\
\text { realisation motives }\end{array}$ & 3.66 & 5 & 1.48 & 33.24 & 3.25 & 4 & 1.34 & 35.62 \\
\hline $\begin{array}{l}\text { Educational/cognit } \\
\text { ive motives }\end{array}$ & 3.65 & 5 & 1.25 & 30.63 & 3.38 & 4 & 1.24 & 32.95 \\
\hline Social motives & 3.13 & 3 & 1.54 & 39.65 & 3.52 & 5 & 1.31 & 32.52 \\
\hline $\begin{array}{c}\text { Indicators on the } \\
\text { questionnaire } \\
\text { as a whole }\end{array}$ & 3.38 & 5 & 2 & 41.84 & 3.3 & 4 & 1.77 & 40.32 \\
\hline
\end{tabular}


As can be seen in the table, the overall motivation and average motivations on each of the seven scales of motives are at an average and high level. In both samples, the highest average value of motivation was for the scale of professional motives. In the Riga and Smolensk samples, this value is 4.3 and 3.7, correspondingly. Considering all scales, the averages of the overall motivation are very close: $M=3.38$ (Riga) and 3.3 (Smolensk); the difference is insignificant (0.08 points). The most common assessment $M d n=5$ in Riga and 4 in Smolensk. However, a high $C o V$ on all scales (sometimes more than $33 \%$ ) indicates a high fluctuation of answers in both samples and atypicality of the indicators $M$ and $M d n$.

With the help of the Statistica program, a statistical comparison of the two groups was made by the average of the overall academic motivation for each respondent. In this aspect, the analysis did not show statistically significant differences in the responses of Latvian and Russian students. The comparison was made using the Wilcoxon-Mann-Whitney $U$ test and the Wald-Wolfowitz criteria. Results of the Wilcoxon-Mann-Whitney criterion are the following: the empirical value of the criterion $U_{l}=0.57$, critical $U_{0}=1.96$; the characteristics of the compared samples coincide at a significance level $p=<.05$. The criterion of Wald-Wolfowitz also shows the absence of statistically significant differences.

However, the analysis reveals some differences in the results of freshmen from the two countries. Students assess the importance of the motivation groups somewhat differently. Table 2 presents the ranking of the motive groups in the two samples.

Table 2

Ranking of motive groups in samples of Riga and Smolensk

\begin{tabular}{|c|l|l|}
\hline Rank & \multicolumn{1}{|c|}{ EKA } & \multicolumn{1}{c|}{ SmolSU } \\
\hline 1 & Professional motives & Professional motives \\
\hline 2 & Educational/cognitive \& & Social \& \\
& Creative self-realisation motives & Communication motives \\
\hline 3 & Communication motives & Educational/cognitive motives \\
\hline 4 & Social motives & Creative self-realisation motives \\
\hline 5 & Prestige motives & Prestige motives \\
\hline 6 & Avoidance motives & Avoidance motives \\
\hline
\end{tabular}

It is gratifying that for freshmen of both universities the most important is professional motivation, which comes first. However, there are differences in the distribution of the 2nd to 4th places. For Riga students, educational/cognitive motives $(M=3.65, M d n=5)$ and motives of creative self-realisation $(M=3.66, M d n$ $=5)$ are in the second place. The first-year students like to learn $(M=3.24)$, they want to acquire solid knowledge $(M=4.15)$, believe that knowledge will be useful in the future profession $(M=4.31)$. The relatively low variation rate on the scale of educational/cognitive motives indicates the statistical consistency of the EKA first-year students' responses.

Smolensk students rated professional motives on average 0.27 points lower with the most common score of 4. In the second most important place for them are social motives of learning $(M=3.52, M d n=5)$ and communicative $(M=3.51, M d n=4)$. For example, a good motivation for them is the dependence of the level of material security in the future and career advancement on academic success (relatively, $M=4.12$ and $M=3.8, M d n=5$ in both items). Thus, the freshmen of Riga are more focused on studying and self-learning as a creative personality, whereas Smolensk students are more attracted to communication and socialisation, which, however, is quite normal for first-year students.

The fact that the motives of prestige in both samples are located in the penultimate place can be considered positive. To become professionals and obtain knowledge is more important for them than the external image of the university and profession. In the last place in both Riga and Smolensk samples are the motives of avoidance. This suggests that freshmen are learning (or not learning) not because they are afraid of being judged for their choice.

On the scale of professional motivation, students of the two countries showed the highest score, so it is worthwhile to consider it more in detail. The group of professional motives consists of six statements, which were estimated from 1 to 5 points. Table 3 provides the key statistics for both samples. 
As can be seen in the table, on all statements Riga students show higher average scores. Riga students put the statement "I want to make full use of my skills, abilities and inclinations for my chosen profession" in the first place $(M=4.52)$, which speaks about the conscious choice of the future profession considering own abilities. In the second place they put the statement "I study because I like the chosen profession" $(M=4.49)$. $C o V$-s in all statements are low (less than $33 \%)$, which indicates the consistency of the opinions of Riga freshmen and the reliability of the average scores.

Table 3

Statistical indicators of professional motivation of first year students of Riga and Smolensk

\begin{tabular}{|c|c|c|c|c|c|}
\hline $\begin{array}{c}\text { Statements of the Scale "Professional } \\
\text { motives" }\end{array}$ & University & $M$ & $M d n$ & Dispersion & $\begin{array}{l}\operatorname{CoV} \\
(\%)\end{array}$ \\
\hline \multirow{2}{*}{ 1. I study because I like the chosen profession } & EKA & 4.49 & 5 & 0.65 & 17.91 \\
\hline & SmolSU & 3.50 & 4 & 1.53 & 35.37 \\
\hline \multirow{2}{*}{$\begin{array}{l}\text { 2. To ensure the success of future professional } \\
\text { activities }\end{array}$} & EKA & 4.09 & 5 & 0.90 & 23.21 \\
\hline & SmolSU & 3.73 & 4 & 1.45 & 32.30 \\
\hline \multirow{2}{*}{ 3. I want to become a specialist } & EKA & 4.45 & 5 & 0.61 & 17.63 \\
\hline & SmolSU & 4.00 & 4 & 1.17 & 27.00 \\
\hline \multirow{2}{*}{$\begin{array}{l}\text { 4. To propose a solution to the most pressing } \\
\text { problems related to the future profession }\end{array}$} & EKA & 3.81 & 5 & 1.10 & 27.53 \\
\hline & SmolSU & 3.16 & 4 & 1.67 & 40.88 \\
\hline \multirow{2}{*}{$\begin{array}{l}\text { 5. I want to make full use of my skills, abilities } \\
\text { and inclinations for my chosen profession }\end{array}$} & EKA & 4.52 & 5 & 0.59 & 16.94 \\
\hline & SmolSU & 3.85 & 5 & 1.46 & 31.38 \\
\hline \multirow{2}{*}{ 6. To become a highly qualified professional } & EKA & 4.42 & 5 & 0.73 & 19.36 \\
\hline & SmolSU & 3.97 & 3 & 1.63 & 32.15 \\
\hline \multirow{2}{*}{ Indicators on the scale as a whole } & EKA & 4.30 & 5 & 0.76 & 20.27 \\
\hline & SmolSU & 3.70 & 4 & 1.48 & 32.88 \\
\hline
\end{tabular}

Smolensk students, on the other part, put studying to become specialists and highly qualified specialists in the first place ( $M=4.00$ and $M=3.97$, correspondingly). The latter statement is more of a control one. On 4 out of 6 statements of this scale, the variation rates in the Smolensk sample are low, which suggests the average scores of these statements are typical. However, not all Smolensk freshmen are sure that they like their choice of profession. The average score for this statement is lower than that of Riga students' by almost 1 point $(M=3.5)$. High variation $(\mathrm{CoV}=35.37 \%)$ proves that many have responded negatively. 13 people give this statement a negative rating (1-2 points), which is $21 \%$ of all respondents. Perhaps the choice of profession for these students was made by parents, or the students chose this area because of low school performance, as they could not enter the program, they wanted because of high competition for entering university. In this case, they clearly have a weak motivation to study at the university. A comparison of the answers to this question suggests itself with the assessment of the statement "I just like to learn" from the scale of educational/cognitive motives. In Smolensk, there are many those who put 1-2 points on this statement: 21 freshmen (33.9\%). In the Riga sample, the number of those who do not like to study is 17 people or $25.4 \%$, which is anyway quite a lot.

The greatest variability of Smolensk students' opinions on the statements in the scale of professional motives is observed in the answers to the question "I want to propose a solution to the most pressing problems related to the future profession" $(\mathrm{CoV}=40.88 \%)$. This suggests that many students do not want to immerse themselves in the profession deep enough to engage in research activities in the chosen field.

To establish the dependence of the overall academic motivation on the responses to individual questionnaire statements, the survey was analysed by rank correlation. It was found that the overall academic motivation of first-year students statistically depends on almost all 34 questionnaire statements. In the Smolensk sample, Spearman's rank correlation coefficient shows a statistically significant correlation between motivation and all but two statements: "Once in the university, I have to study to finish it" and "I study for the sake of fulfilling the duty to parents and school". Spearman's correlation coefficient in the Riga sample gives a statistically significant dependence of the overall motivation on all statements. 
The study tested the hypothesis that the level of student motivation is related to the psychological climate in the student group. To do this, the technique "Assessment of the psychological atmosphere in the team" by A.F. Fidler was applied, in which respondents rate relationships in a group by pointing from 1 to 8 on ten bipolar scales: friendliness - hostility; consent - dissent; satisfaction - dissatisfaction; fascination - indifference; productivity - unproductivity; warmth - coldness; cooperation - lack of cooperation; mutual support - unkindness; attraction - boredom; success - failure.

In general, freshmen of both countries positively perceive the psychological climate in their groups: in both samples, the averages for all ten bipolar scales are below 4 (the lower the scores, the better the atmosphere in the group). Riga students assessed the psychological atmosphere in the group by an average of 2.77 points out of 8 possible. Particularly positive are such manifestations of relationships in the group as friendliness $(M=2.07)$, consent $(M=2.54)$, mutual support $(M=2.54)$ and cooperation $(M=2.45)$. Only on two bipolar scales, the averages in the Riga sample are above three. The "fascination - indifference" has indicators $M=3.36$ and $M d n=3$; the scale of "attraction - boredom" has $M=3.22$ and $M d n=4$ (!).

Smolensk students estimate the overall atmosphere in the group by $M=3.24$ points, which also indicates a positive perception of the psychological atmosphere in the group. However, in general the indicators are slightly less positive than in the Riga sample. Indicators of cooperation $(M=2.76)$, friendliness ( $M=2.81$ points) and mutual support $(M=2.92)$ obtained the best values. The most negative average ratings were found on the scale "productivity - unproductivity" $(M=3.6, M d n=3)$, "fascination indifference" $(M=3.56, M d n=2)$ and "attraction - boredom" $(M=3.50, M d n=3)$.

The calculation of Spearman's correlation between the level of psychological atmosphere in the student group and the overall motivation score reveals a statistically significant dependence (although a weak one) in the Smolensk sample $(r=-0.292 ; p=<.05)$. This dependence is inversely proportional, that is, the better the atmosphere in the group (the lower score on this basis), the higher the motivation of students. The motivation of Smolensk freshmen is particularly positively influenced by the overall atmosphere of success in the group (moderate correlation, $r=-0.33 ; p=<.05$ ).

In Riga sample, no correlation between the overall educational motivation and the level of psychological auspiciousness in the group was found. This may mean that, compared to Smolensk students, Riga students are, on average, more individualists, and their motivation is less driven by the social environment. It should be noted, however, that this result is intermediate, as the issue requires further study and a more detailed analysis of the correlations between individual groups of motives to learning and the scales of the psychological atmosphere.

The study shows that a few months after the start of studying, the academic motivation of first-year students is at an average level. However, for more successful training, it could and should be improved. To increase motivation for learning, one can influence students who do not like learning by changing their understanding of learning. At the same time, the teacher may more often introduce less familiar methods and forms of education, such as the project method, classes in the museum, at work or in the yard of the university. The involvement of students in the learning process is facilitated by an individual approach on the part of teachers, the widespread use of formative assessment, democracy and maximum freedom for students in organising the educational process (e.g., a self-dependent choice of assignment options).

More attention needs to be paid to creating an auspicious psychological atmosphere for learning in student groups. It is quite difficult to influence it by teachers who rarely see students, but it can be done by the curator, employees of the dean's office or SIC (Student Information Centre). Especially in the first weeks and months of the study, joint efforts of student self-government, administration and academic staff of the university are needed, aimed at adapting freshmen to new conditions (individual attention to each student, general conversations-acquaintances a story about the faculty, rites of passage of students, trainings aimed at uniting the team). 


\section{Conclusions}

The study shows that a few months after the start of studying, the academic motivation of first-year students is at an average level:

- professional motives for learning prevail over other motives in the Smolensk and Riga samples, but are more pronounced in the Riga sample; the answers of Riga students are more consistent, the average motivation $(M=4.3)$ is typical for the students surveyed.

- first-year students of Smolensk are more motivated to communicate and socialise than to gain knowledge: their educational/cognitive motives are in the third place (in Riga - in the second, along with the motives of creative self-realisation);

- for the Smolensk sample of students, it was found out that their motivation to learn depends on the psychological atmosphere in the group, especially on the overall atmosphere of success in the student group;

- to increase motivation, one needs to work on improvement of the atmosphere in the student group, by changing the understanding of the study by some students through a combination of both traditional and innovative methods and forms of learning, individual and democratic approaches.

\section{Bibliography}

1. Badmayeva N.T. (2004). Vliyanie motivacionnogo faktora na razvitie umstvennyx sposobnostej [The influence of motivational factor on the development of mental abilities]. UlanUde: Publishing House VSGTU. Retrieved from http://vallos-alien.narod.ru/Creator/Bibl/Mtdusc10.pdf (in Russian)

2. Baljukova I.B., Jakovleva T.S. (2020). Infantil'nost' i professional'noe samoopredelenie studentov [Infantilism and professional self-determination of students]. Socio-anthropological problems of modern education. Pskov: Pskov State University, 35-41 (in Russian)

3. Bartram B. (2020). Higher Education: Contemplating the contradictions, complexities and challenges. In B. Bartram (Ed.), Understanding Contemporary Issues in Higher Education: Contradictions, Complexities and Challenges, Chapter 14. doi: 10.4324/9780429354274

4. Birzina R., Cedere D. (2017). The First Year Students' Perceptions of Higher Studies: a Case of University of Latvia. In V. Dislere (Ed.), The Proceedings of the International Scientific Conference Rural Environment. Education. Personality (REEP), 10. Jelgava: LLU, 40-49. Retrieved from https://llufb.llu.lv/conference/REEP/2017/Latvia-Univ-Agricult-REEP-2017_proceedings-40-49.pdf

5. Boekaerts M. (2010). The Crucial Role of Motivation and Emotion in Classroom Learning. In H. Dumont, D. Istance, F. Benavides (Eds.) The Nature of Learning: Using Research to Inspire Practice. Paris: OECD Publishing, 91-111. doi: 10.1787/9789264086487-6-en

6. Briede B., Peks L. (2014). A constructivist approach in teaching in higher education for getting methodological and reflection competences. In V. Dislere (Ed.), The Proceedings of the International Scientific Conference Rural Environment. Education. Personality(REEP), 7. Jelgava: LLU, 84-89. Retrieved from: https://llufb.llu.lv/conference/REEP/2014/Latvia-UnivAgricult-REEP-2014proceedings-84-89.pdf

7. Borzilova N.S. (2015). Vzaimosvjaz' uchebnoj motivacii i adaptacionnyh vozmozhnostej lichnosti studentov-pervokursnikov [The relationship between educational motivation and adaptive capabilities of the personality of first-year students]. Scientist's Notes, 6. Rostov-on-Don: Southern University "Institute of Business and Law Management", 28-31. Retrieved from http://nauka-prioritet.ru/wpcontent/uploads/2016/09/\%D0\%94\%D0\%B5\%D0\%BA\%D0\%B0\%D0\%B1\%D1\%80\%D1\%8C20151.pdf\#page $=28$ (in Russian)

8. Bustamante J. (2020). College Dropout Rates. Retrieved from https://educationdata.org/collegedropout-rates

9. Fetiskin N.P., Kozlov V.V., Manujlov G.M. (2002). Metodika ocenki psihologicheskoj atmosfery $\mathrm{v}$ kollektive (po A.F. Fidleru) [Methodology for assessing the psychological atmosphere in the team (according to A.F. Fidler)] Social'no-psihologicheskaja diagnostika razvitija lichnosti I malyh grupp [Socio-psychological diagnostics of the development of personality and small groups]. Moscow: Publishing House of the Institute of Psychotherapy. Retrieved from https://www.arhivinfo.ru/2-86082.html (in Russian) 
10. Gottschalk S. (2018). The infantilization of Western culture. Retrieved from https://theconversation.com/the-infantilization-of-western-culture-99556.

11. Hartwell-Walker M. (2018). Ready or Not: Immature But Headed to College. Retrieved from https://psychcentral.com/lib/ready-or-not-immature-but-headed-to-college/.

12. Howey S.C. (2008). Factors in Student Motivation. Retrieved from https://nacada.ksu.edu/Resources/Clearinghouse/View-Articles/Motivation.aspx.

13. Illeris K. (2009). A Comprehensive Understanding of Human Learning. In K. Illeris (Ed.), Contemporary Theories of Learning: Learning Theorists ... in Their Own Words. London, New York: Routledge, 7-20.

14. Jermolajeva J., Silchenkova S., Turusheva L. (2020a). Last year university students' motives for learning and the ways to increase their motivation. In V. Lubkina (Ed.), Proceedings of the International Scientific Conference Society, Integration, Education (SIE), I, 266-275. Rezekne: Rezeknes Tehnologiju akademija. doi: 10.17770/sie2020vol1.4863

15. Jermolajeva J., Silchenkova S., Turusheva L. (2020b). Professional motives as a leading factor of last year university students' learning motivation. In V. Dislere (Ed.), The Proceedings of the International Scientific Conference Rural Environment. Education. Personality (REEP), 13. Jelgava: Latvia University of Life Sciences and Technologies, 70-75. doi: 10.22616/REEP.2020.008

16. Kromydas T. (2017). Rethinking higher education and its relationship with social inequalities: past knowledge, present state and future potential. Palgrave Commun 3, 1. doi: 10.1057/s41599-0170001-8

17. Maslow A.H. (1954). Motivation and personality. New York: Harper and Row Publishers, Inc. Retrieved from http://s-f-walker.org.uk/pubsebooks/pdfs/Motivation_and_PersonalityMaslow.pdf

18. OECD. (2020). Education at a Glance 2020: OECD Indicators. Paris: OECD Publishing, doi: 10.1787/69096873-en

19. Rizkallah E.G., Seitz V.A. (2017). Understanding student motivation: a key to retention in higher education. Scientific Annals of Economics and Business. 64(1), 45-57. doi: 10.1515/saeb-2017-0004

20. Safronova V., Klyukina E. (2019). Some Aspects of Motivating Tertiary Students in Learning Oriental and European Languages. In V. Dislere (Ed.), The Proceedings of the International Scientific Conference Rural Environment. Education. Personality (REEP), 12. Jelgava: Latvia University of Life Sciences and Technologies, 158-164. doi: 10.22616/REEP.2019.020 